Volume 11

Issue 1 Information and Communications

Technologies in Mass Atrocities Research and

Article 13

Response

$5-2017$

\title{
Book Review: Making and Unmaking Nations: War, Leadership, and Genocide in Modern Africa
}

David E. Cunningham

University of Maryland

Follow this and additional works at: https://digitalcommons.usf.edu/gsp

\section{Recommended Citation}

Cunningham, David E. (2017) "Book Review: Making and Unmaking Nations: War, Leadership, and Genocide in Modern Africa," Genocide Studies and Prevention: An International Journal: Vol. 11: Iss. 1:

110-112.

DOI:

http://doi.org/10.5038/1911-9933.11.1.1443

Available at: https://digitalcommons.usf.edu/gsp/vol11/iss1/13

This Book Review is brought to you for free and open access by the Open Access Journals at Digital Commons @ University of South Florida. It has been accepted for inclusion in Genocide Studies and Prevention: An International Journal by an authorized editor of Digital Commons @ University of South Florida. For more information, please contact digitalcommons@usf.edu. 


\title{
Book Review: Making and Unmaking Nations: War, Leadership,
} and Genocide in Modern Africa

\author{
David E. Cunningham \\ University of Maryland \\ College Park, MD, USA
}

Making and Unmaking Nations: War, Leadership, and Genocide in Modern Africa

Scott Strauss

Ithaca and London, Cornell, 2015

386 Pages; Price: $\$ 79.95$ Hardback

Reviewed by David E. Cunningham

University of Maryland

Genocide occurs with disturbing frequency. A large body of research from scholars writing in a variety of disciplines seeks to explain why genocides happen. This scholarship has identified factors associated with genocide-such as armed conflict, autocratic governments, ethnic divisions, and a low level of trade openness - and has led to the development of advanced statistical models to forecast genocide. Scholars and practitioners pay close attention to the possibility for genocide when new armed conflicts emerge or instability breaks out around elections or other contentious events.

Yet, while genocide is distressingly common, it is relatively rare when compared to the factors identified as associated with it. Many countries are autocratic, ethnically divided, and experience armed conflicts without genocide occurring. Forecasting models do a reasonable job of predicting occurrences of genocide but generate many false positives, in which the likelihood of genocide is seen as high but it does not happen. While the scholarship on genocide has made significant advances, it has been limited because it has tended to focus on cases of genocide without making comparisons to similar cases where genocide was plausible but did not occur.

In this excellent book, Scott Strauss sets out to advance the literature on genocide by theoretically and empirically treating it in a comparative context. Theoretically he does so by both analyzing the factors that encourage actors to contemplate genocide as well as the factors that encourage restraint when there is a real possibility of engaging in genocide. Empirically, Strauss conducts detailed case studies in which he compares cases of genocide to others where he argues genocide was possible, but did not happen.

Strauss's argument focuses on national elites, because he argues that genocide almost always requires elite coordination and, while local leader and individual participation is important, in the absence of leadership by national elites it is very unlikely. He argues that genocide is a type of political violence with a fundamentally different agenda than other kinds such as insurgency, terrorism, riots, or counter-insurgency because it is designed to eliminate a perceived enemy, rather than to change the behavior of that actor. As such, Strauss argues that elites will only contemplate genocide when they believe they face a grave and immediate threat.

The focus on threat is not new, in fact, it is one of the main arguments in the existing literature. However, Strauss views threat by itself as an insufficient explanation, as elites have multiple options for responding to grave and immediate threats and because these types of threats to leaders are much more common than genocide. Strauss argues that leaders, in the face of grave and immediate threats, will only choose genocide if preexisting ideological frameworks - which he refers to as "founding narratives" - view the primary political community (such as a specific ethnic group) as a sub-set of the overall population of the state and see a specific group of people as representing the threat to that primary community. It is thus the combination of the strategic environment (armed conflict which represents a significant threat) with ideology that determines when genocide occurs.

Strauss examines and develops this argument through five cases, two in which genocide and mass killing occurred (Rwanda and Darfur) and three that had similar circumstances as those two but where genocide did not occur (Cote D'Ivoire, Senegal, and Mali). All five cases are in Africa, 
which allows him to hold constant a number of other factors that could influence genocide and also to examine the role of founding narratives in states that are relatively young.

Strauss's argument is most clearly supported in the case of Rwanda, which is also the case he has researched in the most depth. In Rwanda, there was a clear military threat, as the rebel Rwandan Patriotic Front had the upper hand militarily over the Rwandan army in a civil war at the signing of a peace agreement in the summer of 1993. That peace agreement led to a temporary suspension of hostilities, but was not fully implemented, and it broke down completely when the plane carrying Rwandan President Juvenal Habyarimana was shot down and he died. There has been much controversy over who is responsible for the downing of the plane, Strauss argues (and I agree) that it was almost certainly the RPF. To some degree the question is irrelevant, as many Rwandan Hutu elites believed the RPF shot down the plane to re-start the war, and the RPF did in fact return to the battlefield very quickly. Massacres of Hutu opposition politicians and Tutsi civilians began hours after the plane crashed, and over the next 100 days around $75 \%$ of the Tutsi resident population was killed.

All of these details are well known, and the typical story of the Rwandan genocide is that Habyarimana's plane being shot down allowed Hutu hard-liners in the Rwandan military to begin a genocide they had been planning for months. However, Strauss demonstrates convincingly, drawing on years of research by the International Criminal Tribunal for Rwanda as well as his own extensive field research, that the initial response to the resumption of the war was more focused on countering the RPF threat directly, and that the plan to wipe out the Rwandan Tutsi population developed in the days that followed. Genocide was enabled by the founding narrative that Rwanda was a state for the Hutu that had come into existence by both defeating the European colonizers and Tutsi-led monarchy and feudalism. This narrative allowed for overcoming forces for restraint at the individual, local, and national level and combined with the grave and imminent threat of the RPF (who did, three months later, win the war) to allow the slaughter of 500,000-800,000 Rwandan Tutsi.

The case of Darfur is an interesting one for Strauss. It has similar elements to Rwanda, in that the founding narrative of Arab-Islamic nationalism excluded a large element of Sudan's population. However, the Darfuri conflict had a key difference-while the RPF was a very real military threat to the Rwandan government, the Darfuri rebels never posed a direct military threat to the government in Khartoum. However, the fractious nature of politics in Sudan and the history of armed conflict meant that the government saw any threat to the Arab-Islamic identity of the state as grave and responded very harshly to it. In doing so, it worked with groups on the ground in Darfur who saw the rebels as a very real direct threat to their interests.

The three "negative" cases all share similarities with Rwanda and/or Darfur, but have key differences in the ideology guiding elite decision-making. In Cote D'Ivoire, international actors saw genocide as a real possibility, as two civil wars and controversial elections combined with the emergence of an explicitly nationalist ideology ("Ivorité") seemed to set the stage for mass categorical violence. Yet, the country avoided genocide, and Strauss argues that this is because of several domestic factors, the primary of which was the first President Houphouet's founding narrative emphasizing dialogue and multiethnicity. In Mali, like Darfur, a peripheral insurgency was fought between groups divided along a racial cleavage, but again genocide did not occur, which Strauss attributes to an elite-led ideological focus on dialogue as the way to resolve political disagreements. In Senegal a Christian ethnic minority has fought a long-running secessionist war against a majority ethnic group that is primarily Islamic and the conflict is very clearly perceived in identity terms. However, a founding narrative of pluralism prevented genocide from occurring in Senegal.

The five case studies in this book are very well researched and provide strong support for the theoretical argument. The reader of this book learns much about these individual cases, genocide, as well as nation-building in African states. I finished the book hungry for more, which is not a criticism, but rather a reflection of how stimulating and thought-provoking it is.

In particular, I would be interested in seeing more research in two areas. First, the book here is focused on Africa, a concentration which makes sense both for telling a clear story about nationbuilding there and from a research design standpoint. Strauss does make reference to other cases 
outside of Africa, including Guatemala and Nazi Germany. However, it would be interesting to see how well the theoretical argument here works to explain cases outside of Africa, particularly in countries that are not nearly as new as the states studied here. In many cases, the "founding narratives" emphasized here were established at or soon after independence, less than fifty years before the events being analyzed and some of the people instrumental in these events were present at the formation of these narratives. Looking at states that are outside of Africa could allow for analyzing how and when founding narratives shift and the effect that this has on genocide.

The second area is related. I was persuaded by the discussion of the role of founding narratives in each of the five cases here. However, I was less clear on how one would identify a founding narrative prior to a period of crisis where it is anticipated to have an effect. While I find the argument here very helpful in understanding cases that have occurred, I wonder about the utility in predicting future genocides. Strauss provides a very helpful appendix focused on identifying the risk of genocide, but future research that established more objective indicators of ideological narratives that are likely to be related to genocide would be useful.

In summary, Strauss's book makes a clear theoretical and empirical contribution to scholarly understanding of genocide and the process leading up to it. It should be required reading for anyone interested in understanding this important topic and should generate substantial additional scholarly research. 